\title{
Crossing the Threshold of Cyborgization
}

\author{
Anton Grinin ${ }^{1}$ \\ Leonid Grinin²
}

${ }^{1} \mathrm{PhD}$ in Biological Sciences, Moscow State University

${ }^{2} \mathrm{PhD}$, Professor, The Institute of Oriental Studies of the Russian Academy of Sciences (RAS), Moscow,

Vice-Director of the Eurasian Center for Big History \& System Forecasting

With the support of the Russian Science Foundation grant 20-61-46004

Correspondence I Anton Grinin, algrinin@gmail.co; Leonid Grinin, leonid.grinin@gmail.co

Citation I Grinin, Anton, and Leonid Grinin. 2020. “Crossing the Threshold of Cyborgization.” Journal of Big History 4 (3): $54-65$.

DOI I https://doi.org/10.22339.jbh.v4i3.4330

K E Y W O R D S

Cyborgization

Big History

Collective Learning

Cybernetic Revolution

\begin{abstract}
A B S T R A C T
Cyborgization is a hot topic these days. This is an intriguing process that is the subject of many futuristic novels and which at the same time takes place right before our eyes. In the present article we discuss the development of cyborgization, its place in Big History, its background and future directions, as well as the problems and risks of this interesting process. The authors are concerned about the question of whether the time will come when a person will mainly or completely consist not of biological, but of artificial material. The article also touches upon other problems and risks associated with future scientific and technological progress.
\end{abstract}

\section{Introduction: Cyborgization in Big History}

The process of cyborgization can be considered as part of the technological evolution. On the whole, all human history, especially the last few centuries, is the history of the triumph of science and technology. Since the advent of Homo sapiens, people have been tied to technology (given the popular idea that labor transformed apes into humans, while the labor consisted primarily in the "production" of stone tools). As a result, mankind, the creator of technology, becomes increasingly dependent upon it (L. Grinin and A. Grinin 2015, 2016). Today, technology serves almost every aspect of our lives, but in the near future, more serious transformations are possible when complex mechanisms and technologies can merge with the human body and mind.

Cyborgization is the process of replacing parts of the human body with cybernetic implants. To some extent, this process began a long time ago. The earliest evidence of prosthetics is recorded in Ancient Egypt. Researchers have discovered a prosthetic big toe made of wood and leather in
Cairo, dating from between 950 and 710 BC (Finch et al. 2012). Another oldest recovered prosthesis was found in a tomb in Capua (Italy) in 1858 , dated from the Samnite wars in 300 BC. It was made of copper and wood (Bennett Wilson 1964). In the Middle Ages, prostheses of iron were made by armorers for knights who had lost limbs in battles (Sellegren 1982). A famous example is the prosthetic arm of the German Imperial Knight, mercenary, and poet Götz von Berlichingen, made at the beginning of the $16^{\text {th }}$ century, which had a complex mechanism for that time (Goethe n.d.).

Progress in the field of artificial body parts has become so significant that almost every one of us today is a bit of a cyborg. Without a doubt, most people on the planet have either false nails or artificial teeth or glasses or contact lenses. The FDA estimated that 324,200 people had received cochlear implants worldwide (Technavio 2016). In 2016 the Ear Foundation in the United Kingdom estimated the number of cochlear implant recipients in the world to be about 600,000 (The Ear 
Foundation 2017). Artificial heart (DeVries et al. 1984), kidney, liver, pancreas (Stamatialis et al. 2008), bionic eyes (Boyle et al. 2003), bionic limbs (Farina and Aszmann 2014) and many more are reality now.

Unfortunately, although cyborgization is actively developing, there are not many theoretical concepts that shed light on the origin and trends of this process. Among the popular ones are transhumanism, whose fundamental ideas were first put forward in 1923 by the British geneticist J. B. S. Haldane (Haldane 1924; Huxley 2015), and the singularity by Ray Kurzweil (2010).

We suppose that the origin and trends of cyborgization can be well understood within the framework of Big History. Cyborgization is an important milestone in Big History. It is the intersection of the human (or Upper Paleolithic) revolution and a new "post-human" revolution whose consequences are not yet clear in many respects, but which will obviously start the era of an intensive impact on the human body. We see the origins of cyborgization in collective learning, which is the sixth threshold of Big History. "Collective learning" is a term adopted by David Christian (Christian 2012, 2018). It is a sufficiently powerful system of communication and sharing information in such volume and with such precision that new information accumulates at the level of the community and even the species (Christian 2015). The collective learning process has become the basis for the development of technology, which provided the next important thresholds: "Agriculture" and The Modern Revolution" (David Christian et al. 2014; Spier 2015). The future ninth threshold in our view will be the threshold of cyborgization. Collective learning will develop into a global system of information exchange between the human brain and computer interfaces. Thus, a new system of collective learning will appear, which will give an impetus for the further development of Big History, or, perhaps, it will start a new kind of evolution. As R. Dawkins writes, "Whenever conditions arise in which a new kind of replicator can make copies of itself, the new replicators will tend to take over and start a new kind of evolution of their own" (2006).

\section{The Cybernetic Revolution}

We are now at the threshold of the posthuman revolution. Perhaps, it will be less radical than the transhumanists and other followers of practical immortality imagine. Anyway, we are speaking about a considerable extension of life, the replacement of an increasing number of organs and cells of the human body with nonbiological materials, and the implantation of electronic and other elements into the human body.

In the 1950 and 1960 s the world (first, the developed countries) became a witness to the largest technological revolution in history, which continues to this day. At the end of the twentieth century, the achievements of this revolution, especially in the field of information technologies, has spread all over the world. We call this revolution the "Cybernetic revolution," because cybernetics is the science about information and its transformations in various complex systems ( $\mathrm{L}$. Grinin and A. Grinin 2015). During its first phase (from the 1950s to the present day), the Cybernetic revolution has radically changed information processing and provided a breakthrough in the regulating of complex processes in a wide range of natural and artificial systems that became part of the production process. In the future it will provide the ultimate breakthrough by creating a fundamentally new environment, a world of selfregulating systems. The Cybernetic revolution became the third largest production revolution in the history of humankind after the Agrarian (Neolithic) and Industrial ones, but it has not yet ended. We consider the revolutionary changes, which the world will face in the coming six to seven decades, will happen during the second (the final) phase of the Cybernetic revolution. ${ }^{1}$

The development of cyborgization is one of the trends in this period that has important implications for the coming phase of the Cybernetic revolution. First of all, it is a general trend resulting in the improvement of human quality of life and longevity. Second, it is a trend in the development of various self-regulating systems and technologies (defined as those systems and technologies that can operate without direct human intervention). 
Some of the most important drivers of this final phase of the Cybernetic revolution will be in medicine: additives, bio- and nanotechnologies, robotics, information and communications technologies, and cognitive technologies, which together will form a sophisticated system of selfregulating production. We abbreviate this complex as MANBRIC-technologies. There are reasons why medicine will become the core of the Cybernetic revolution. First, medical services are rapidly growing at around ten per cent of the world GDP (WHO 2020), and will continue to grow. Second, peripheral countries develop a huge middle class, with a reduction in poverty and illiteracy. As a result, their focus will shift from the elimination of unbearable conditions to the problems of raising the standards of living, health care, etc., so, there is a great potential for the development of medicine.

The third important issue is the problem of population aging (Vollset et al. 2020). An aging population will soon become characteristic not only of developed countries, where it will become crucial for democracy, but also for a number of developing countries, in particular, China and India. The problem of pensions will become more acute (as the number of retirees per worker will increase) and at the same time the lack of a qualified labor force will increase (which in a number of countries is critical). Thus, countries will have to solve the problem of labor force shortages and pension contributions by increasing the retirement age by ten to fifteen years. It also applies to people with disabilities whose full involvement in the work process could be realized thanks to new technologies and medical advances. At the same time the birth rates in many developing countries will significantly decrease (Vollset et al. 2020). On the whole, these conditions will entail government involvement, as well as major investments, business activity, and science development in order to provide a breakthrough in health care. The formation of such unique conditions is necessary for the beginning of a new phase of the Cybernetic revolution. This, most likely, will also be facilitated by the danger of pandemics (as it is shown by COVID-19), which will require urgent solutions in medicine and will necessarily require large finan- cial resources.

\section{Leading Technologies of Cyborgization}

There are a growing number of self-regulating technologies in different branches of medicine even today, for example, life support systems or artificial organs. Other systems only move in the direction of self-regulation, for example, flexible controlled instruments, which allow doctors to perform a surgery in the most inaccessible parts of human body with minimal incisions (often using endoscopes and video cameras). One can anticipate that in the nearest future many operations, robotic operations, will be conducted without human participation at all (Fortune Business Insights 2019).

We suppose that many self-regulating systems will play a crucial role in cyborgization, among them different biosensors or bio-chips. This is a new trend representing a combination of medicine and nanotechnologies. Biochips are able to register a wide range of physiological changes and respond to them or perform specific actions. In the long term biochips will permit continuous control of a person's health. Because of the constant diminishing of a resistor's size (Peercy 2000), some biochips are so small that they can be inserted into cells (so they are often called nanochips). These biochips can be used for different purposes, for example, for targeted drug delivery (Wang et al. 2015). Further miniaturization will allow the creation of a system, which will constantly monitor important parameters of the body, record activities, and track the location of a person. Such systems will be common in the second phase of the Cybernetic revolution.

Another important self-regulating technology is the brain-computer interface (BCI). This is an interaction between the brain and computer systems that can be realized via electrode contact with the skin on the head or via electrodes implanted into the brain. Today BCIs are widely used, especially in medicine, for example, in artificial visual systems, or in bionics. In the future they will significantly improve rehabilitation for people with strokes, head trauma, and other disorders. BCIs can become an essential way to make artificial parts of the body directly controlled by 
the brain. It will be especially important in orthopaedics or bionics. According to the World Health Organization, more than one billion people are living with some form of physical disability, and about 190 million adults have a major functional difficulty (World Bank 2011).

Another important issue will be the manufacture and use of artificial organs, which are complex self-regulated systems. At present, there are many different artificial organs: heart, ear, eye, limbs, liver, lungs, pancreas, bladder, ovaries, trachea, etc. (Murphy and Atala 2014; Stamatialis et al. 2008). Artificial organs will also be able to change human reproductive capabilities. The artificial womb will be able to provide an opportunity to have children for all people irrespective of age and gender (Corea 1986; Rosen 2003).

Of course, in reality, cyborgization will be based on a combination of these and other technologies. Also, the same result can be achieved by means of different technologies, for example, a bionic eye will most probably be an artificial eye (an artificial copy of the natural one). It can be a camera, integrated into eyeglasses, which captures images and transmits them to the optic nerve via BCIs. (Such technology already exists; see, for example, Ong and da Cruz 2012).

Speaking of cyborgization, it is impossible not to mention the development of robots. Robots will develop as highly self-regulating systems and will spread to virtually every area of our lives. The robotics market is going to grow (Technavio 2020), especially healthcare robots, for instance surgical robots, as we mentioned before, or robots for rehabilitation therapy (Burgar et al. 1999).

\section{Waiting for Radical Changes}

Many researchers suppose that we have already approached, or are approaching, some significant quite serious transformation, and that human civilization will experience considerable changes in the next decades. Some speak about approaching the singularity point. This is a certain unprecedented level of technological progress, after which the curve of technological development will change to a new trend. It is a popular idea that after the singularity point a new radical phase of human development will start. (Here we should especially mark out Raymond Kurzweil's works, e.g. (Kurzweil 2010), which can be evaluated as an extreme technological optimism).

We assume that technological growth will not be infinite, but our analysis shows that there are a number of reasons to expect that in the forthcoming decades the global technological growth rate will return for some time to a hyperbolic trajectory when the final phase of the Cybernetic revolution begins (Grinin et al. 202ob). This acceleration will continue up through the late twenty-first century. According to our calculations, technological growth at the end of the twenty-first century will gradually slow down to the singularity point, approximately in the year 2106. It is significant that the global aging factor will play a leading role here. After the singularity point, the rate of technological progress will slow down compared to the previous epoch, and the pattern of scientific-technological development itself will change dramatically. However, toward the end of the twenty-first century we should expect a rapid increase in the possibilities for changing human nature.

\section{From a Human to a Cyborg}

A popular idea in the study of transhumanism suggests that cyborgization will develop by placing the brain and consciousness in an abiotic immortal body. Immortality in general is one of the main concerns of transhumanism (Fukuyama 2004; Haldane 1924; Hansell 2011; Huxley 2015; More 2013). To what extent is this possible? On the one hand, this direction seems logical, as medicine has been moving this way for many decades. Currently, bioprinters can create different tissues and organs (Murphy and Atala 2014), and neural interfaces allow the control of some devices and equipment "by power of thought" (Schalk et al. 2004). Besides, it looks like there will be an increase in technologies in terms of the rapprochement of people and artificial systems, in particular in the construction of humanoids (Hirose and Ogawa 2007). Since these robots will be used not only for work and entertainment, but also for very close or even intimate contacts 
with people (Yeoman and Mars 2012), the borders between the human and artificial anthropomorphous systems might start dissolving. Already we have technologies such as virtual reality, where it is becoming difficult to distinguish reality from illusion (Burdea and Coiffet 2003).

On the other hand, over millions of years, biological evolution has balanced all the elements of organisms and their functions in an optimal and efficient (but sensitive to change) way. It is doubtful that the human brain is able to work without the body because the main purpose and function of the brain is to control the body. It also seems irrational to change all organs and parts of the body, usually most of which work fine. It might be much more efficient and less expensive to change only broken or less durable parts. It is likely that the process of cyborgization will never go too far; it will always remain "supplementary" for the biological components of organisms, capable of both significantly improving the quality of, and prolonging, life.

Today, also exists an opportunity to create artificial biological tissues and parts of the body by means of stem cells or other biotechnologies. We suppose that this path of "mending" the body will be the most common. In the case of basic vital organs, such as the heart, lungs, liver, etc., mending can be preferable and more effective than the introduction of artificial non-biological organs. Even today, we know a case when a person's heart was successfully replaced six times (and a kidney one time). ${ }^{2}$ Now only a very rich person can afford it. However, in the future it will be possible "to mend" quite a large number of people by means of laboratory-grown organs.

\section{Systematizing the Risks}

When new medical technologies are introduced, there is, initially, euphoria, but later come an understanding of the problems that new technologies can bring, an awareness of the risks involved, and then sometimes restrictive measures to reduce the perceived negative consequences. We may ask, then, why discuss the dangers today, if they will not come soon? The fact is that the future can turn out to be quite unexpected and even terrible. It is necessary to anticipate and think about all these issues in advance.

\section{Ethical and Moral Problems}

The development of artificial organs, biochips, genetic engineering, etc., raises questions: What will future humans be made of-natural biological or artificially made biological substances, or will they be entirely non-biological beings? How will humans reproduce? How will the brain and consciousness function? Any of these options will dramatically change human fundamental institutions, including morals and interpersonal relations. Morality and human relations do not exist separately from technology, especially from human physiology and, in a broader sense, from the biological basis. They are the result of complex sociobiological evolution and may disappear after the loss of its material biopsychic shell.

We assume that cyborgization as a whole is a process of the transformation of human nature by changing the biological and adaptive abilities of a person. Real cyborgization comes with a change in a person's feelings and consciousness. A recent study presents a conceptual framework for the development of cyborgization, which should be based on the collaboration and fusion of biological and AI units that will shape the intelligence of cyborgs (Wu et al. 2016).

The moral side of the cyborgization is not a new problem (Bernal et al. 1929; Haldane 1924). With increasing technological development today, we can read more specific studies on this topic, such as the impact of the ethical judgment of others on a person's decision to become a cyborg (Pelegrín-Borondo et al. 2020), or even on the ethical issues of cybo-animals, that is, the modification of the body parts of animals with electronic or mechanical devices, such as a cyborg beetle (Xu et al. 2020).

An important problem is raised by Bill Joy about increasing dependence on machines. This weans humans from thinking and solving problems, thus eliminating any practical choice, since all the decisions will be machine-made. Yet, Joy probably overestimates when writing, "The human race might easily permit itself to drift into a position of such dependence on the machines that it would have no practical choice but to 
accept all of the machines' decisions" (2000, 2). Possibly, Joy also exaggerates when he writes, "Eventually a stage may be reached at which the decisions necessary to keep the system running will be so complex that human beings will be incapable of making them intelligently. At that stage the machines will be in effective control. People won't be able to just turn the machines off, because they will be so dependent on them that turning them off would amount to suicide" $(2000,2)$. In the future, when the systems will perform most of the human mental work, our brain will be able to work less and, therefore, can become weaker than the brain of the modern person, just as muscles of many our contemporaries, who have no need of physical activity, weaken. Naturally, more systems facilitating and supporting intellectual work will appear. Here the positive feedback will come to the fore: mind does not want to work, devices facilitate its work, and the mind weakens even more. Therefore, it is not surprising if in the future "a mental gymnastics" will be promoted as an exercise, similar to simple physical activities today. Nevertheless, the danger of heavy reliance on technological systems is not so speculative. This is an important moral issue since the exploitation of this reliance is quite possible, and the future "freedom of choice" for independent thinking is unclear.

Another important moral problem is the resistance to scientific-technological progress, which has a long history. The best known example is the Luddites, a radical organization of English textile workers who destroyed machinery as a form of protest in the nineteenth century (Binfield 2004; Jones 2013). Each manifestation of this fight against machinery or technology was caused not only by obscurantism, but also by real, grounded fears, since so-called progress would often exacerbate the situation, lead to many bankruptcies, and throw overboard many professions; sometimes it would even desolate whole cities and territories and also often deteriorate the quality of products. Sometimes it opened unexpected opportunities for abuses or was the source of a desperate social fight and oppression. Nevertheless, nobody managed to slow down this process. The toughening requirements for new drugs, banning GMO or cloning today, as well as many other things, are modern manifestations of this fight. It is clear that many of these restrictions and bans are absolutely necessary. On the one hand, it is difficult to expect that it is possible to get the development of scientific and technical progress under a full control. On the other hand, progress in the fight for the environment-oriented production of safe drugs shows that it is quite possible to achieve a certain level of control here. In general, the mechanism of minimizing the damage from innovations consists in establishing certain institutes and rules optimizing the control over technologies; but it is especially important to make it beforehand.

\section{The Irreversible Demographic Transforma- tions}

Each phase of a production revolution is connected with demographic change. During the initial and intermediate phases of the Cybernetic revolution (the phases we are now in), a tremendous growth in world total population has taken place and is continuing. This growth is occurring primarily in developing countries and is an ongoing trend in the demographic revolution of the industrial era. On the other hand, in developed countries the demographic revolution has been completed by the so-called demographic transition, which means a decrease in birth rate. At the same time, life expectancy and the quality of life have increased considerably. The demographic transition is actually the result of the initial phase of the Cybernetic revolution. Not without reason, in an increasing number of developing countries, the fertility rates have been declining; in some of them we also observe a noticeable population aging. During the Cybernetic revolution demographic structure has significantly changed. It has transformed from pyramidal (where children and youth make the main part of the population) to rectangular, where the number of older persons is almost equal to the number of youth. (For more information about global aging and technological progress, see L. Grinin et al. 2020). In the coming decades, we will observe an aging of the world population, as a result of which its structure will take the form of a reverse pyramid (where the 
number of children and young cohorts will be smaller than that of the elderly people). In some developed countries the life expectancy can increase up to 95-100 years old, and generally, it can reach the level of today's most successful countries (such as Japan), that is $80-84$ years, but it may even become higher (Statista 2015; Vollset et al. 2020). Meanwhile, an especially rapid growth of elderly cohorts will be observed in the next three decades. As a result, in three decades the world will be divided not into the first and third worlds, but into the worlds of old and young nations. By this time, an aging population will be noticeable in most countries of the world (with the possible exception of African states). At the same time, the slowing down of fertility rates, and the exhausted demographic dividend in most countries of the Third World, will lead to considerable changes in the demographic structure, and the percentage of children and youth will decrease while the proportion of the elderly people will increase (L. E. Grinin et al. 2016; Vollset et al. 2020).

\section{The Decline of Democracy and the Struggle between Generations}

Population aging can lead to the decline of the democratic system. Democracy can evolve into gerontocracy, from which it will be difficult to escape (Berry 2012; Tepe and Vanhuysse 2009). A crisis of democratic governance is quite probable in the context of the struggle for votes. With growing life expectancy and a reduction of youth as a share in the population structure, the number and role of elderly people will inevitably increase along with a probable sexual distortion: women in the western countries and men in some eastern countries. Also, since the elderly generation is sometimes more conservative in its preferences and habits, it can influence the choice of policy and many other political, social and economic nuances that can disadvantage young and middle generations.

Especially alarming is the fact that growing life expectancy can cause a conflict between generations since an increasing number of elderly people will require an increase in working age and working capacity by ten to twenty years or more.
In addition, we will see the full involvement of people with disabilities in the workforce due to the new technical means and advances in medicine--although even within the category of disabled workers there will be a generational gap where the young are impeded by the old. Furthermore, an elderly population can contribute to society's growing conservatism, which will both slow technological growth and make it difficult to rehire, retrain, and retain elderly workers as the technology changes anyway, even at a slower pace as predicted. Negotiating these generational differences will remain a challenge and may eventually force societies to adopt a form of institutional "ageism" in order to allow young people to enter the workforce in the world with high expected life duration.

It is important to note that such a turn to gerontocracy will be most quickly achieved in European countries and in the USA. These countries have the strongest democratic traditions, but they are also states wherein the ethnocultural imbalance is pronounced. Thus, in the future, in the USA for example, one can expect an opposition between the young Latin and elderly white population, while in Europe it will be between a younger generation of Muslims and older, white, Christian populations. It means that the NorthSouth divide will be reproduced in every country where the elderly indigenous people will live alongside a much younger population having different cultural traditions. The conflicts between generations in these countries caused by the above-described crisis of democracy will inevitably affect the fate of the whole world within globalization.

\section{The Geopolitics of an Artificial Reproduction}

At the end of the last century, it became clear that the opportunities to influence human genome and reproduction can generate a plethora of complex social, political, ethical and legal problems in the future. Nevertheless, modification of human embryos has already begun. For example, in 2015 China declared the conducted work on modification of the human embryo (Cohen 2019), as well as Russia in 2019 (Cyranoski 2019). If such researches and methods of rearing 
children outside the maternal placenta develop, the structure of population reproduction will change dramatically. We have considered this issue with respect to the breaking links between generations, but there is also a global aspect. Will the countries and the world in general be ready for such changes? Will some countries not want to derive benefit from their demographic advantages (which would be quite a natural course of things)? There is some room for imagination. On the one hand, it is obvious that in the future, when creating some planetary structures and developing quotas for different states, a country's population number will become much more important than it is today, especially in international relations. (Today a country's status is rather measured by its wealth and military power.) Will the West accept that countries with a much larger population will dictate their terms? On the other hand, why do not some political elites use new reproductive technologies and, for example, launch a population growth race.

\section{Conclusion: Between Technological Opti- mism and Reasonable Caution}

The faster changes proceed, the more difficult it is for society to follow them and the more heterogeneous those changes become both in social and often ethnocultural terms. During the cybernetic revolution, the amount of information increases dramatically. This makes it difficult for many people to learn new technologies and divides the society. "The young see themselves as 'digital natives,' and look down a bit on the 'digital immigrants,' the elderly who grew up with books and pens and paper," write the presidents of the Club of Rome (von Weizsäcker and Wijkman 2018, 46). In some way technological progress accelerates itself by increasing the necessity to adapt and to learn and to rely more and more upon technologies. This forms a new collective learning, which will be a combination of human experience and technological capabilities and which will give impetus for the future ninth threshold and the further development of Big History.

Human power increases with the growth of technology, but along with this many previously unknown problems occur. That is why, if we want to make use of the new opportunities (and why shouldn't we?), it is necessary to foresee problems and to minimize their consequences and "future shock." Unfortunately, mankind does not learn much from its own mistakes and pays little attention to future problems. It is also rather difficult to foresee problems; therefore, we need institutions or administrative-legal systems to take technological development under control and to develop it in cooperation with the technologies themselves while preserving their functionality. However, for this purpose it is necessary to regulate the rate of scientific and technological progress in the world. We believe that sooner or later it will become possible; although, unfortunately, so far it is unachievable, because the competition among countries is primarily based on the different levels of economic growth. It becomes obvious that the control over hazardous changes will also require certain political transformations that can turn extremely complicated and sensitive (L. Grinin and Korotayev 2013).

Societies have always had two main regulators without which they cannot exist: morals and laws, both of which are based in turn upon the psychological structures of those societies (L. Grinin and A. Grinin 2016). As technologies develop faster, it seems morals are becoming less clearly defined and are failing to find a new balance. It is possible that beyond a certain limit of the speed of scientific-technological development, a noticeable destruction of morals, or their disintegration into different varieties, may begin. It is all the more dangerous as powerful technological opportunities for the transformation of the human body develop. Due to the lack of moral restrictions and the desire to make big profits, various dangerous phenomena may prevail: from the fashion for body corrections to attempts to become superhuman with the help of new medical technologies.

Having appeared first in agrarian and craft societies, law became mature during the period of industrialism (while the rule-making process takes place within any society). The law, being more flexible than moral codes, nevertheless demands a certain stability, which is hardly 
achievable in conditions of rapid technological change (Lem 1968, 269). Societies and their legal systems can become weak in the face of technological innovations, and sometimes there are direct conflicts between those technologies and the law. As Lem notes, "the intensity with which 'simplifying' technology undermines values is positively correlated with their effectiveness." This means that the more effectively technologies solve certain issues, the more they change a society's moral and legal pattern, the consequences of which are realized only much later. In what ways future societies will organize themselves is not yet clear. In earlier epochs, moral and legal codes were the two feet on which societies stood, firm$\mathrm{ly}$, and if there were any imbalances, for example, if laws were insufficiently developed, a society could become destabilized. Figuratively speaking, however, in the future, if one "foot" (morals) disappears, and the other (the law), weakens, will societies be able to keep their balance on such weak bases and at such a high rate of change?

It is difficult, and actually senseless, to try to impede progress. However, there is always the question of what we define as progress in any given epoch. We must always ask what the costs are? It is preferable not to rush into making changes when we are unsure of their consequences. Caution is called for. Rapid and unplanned technological development in the name of a vaguely defined "progress" can lead to new and unforeseen moral, legal, and economic problems; they can cause disputes, conflicts, trade wars, and phobias. Public consciousness always lags behind technological development. Uncontrolled technological development can be compared with the Roc, the legendary bird from the Arabian Nights that can carry humanity to safety but demands human sacrifice. Are we ready for it? What are we prepared to sacrifice for the sake of progress?

\section{References}

Bernal, J. D., A. Maurois, and S. Radhakrishnan. 1929. The World, the Flesh and the Devil. London: Kegan Paul, Trench, Trubner.
Berry, Craig. 2012. The Rise of Gerontocracy? Addressing the Intergenerational Democratic Deficit. UK: Intergenerational Foundation.

Binfield, K. 2004. Writings of the Luddites. Baltimore: JHU Press.

Boyle, J., A. Maeder, and W. Boles. 2003. "Scene Specific Imaging for Bionic Vision Implants." In Proceedings of the 3 rd International Symposium on Image and Signal Processing and Analysis, 2003. ISPA 2003. (1): 423-427. Presented at the 3 rd International Symposium on Image and Signal Processing and Analysis, 2003. ISPA 2003., Rome, Italy: IEEE. https:// doi.org/10.1109/ISPA.2003.129693.

Burdea, G. C., and P. Coiffet. 2003. Virtual Reality Technology. New York: John Wiley \& Sons.

Burgar, C. G., P. Lum, P. C. Shor, and H. Loos. 1999. "Development of Robots for Rehabilitation Therapy: The Palo Alto VA/Stanford Experience." Journal of Rehabilitation Research and Development 37, 663-73.

Christian, D. 2018. Origin Story: A Big History of Everything. New York, Boston, London: Little, Brown and Company.

Christian, David. 2012. "Collective Learning." In Berkshire Encyclopedia of Sustainability. Volume 10, The Future of Sustainability (49-56). Great Barrington, MA. Berkshire.

---. 2015. "Part II. GLOBAL HISTORY AND MODERNITY Swimming Upstream: Universal Darwinism and Human History." Globalistics and Globalization Studies: Big History \& Global History, 138.

Christian, David, C. S. Brown, and C. Benjamin. 2014. "Big History: Between Nothing and Everything." Asian Review of World Histories 2 (2): 267-269.

Cohen, J. 2019. "The Untold Story of the 'Circle of Trust' Behind the World's First Gene-edited Babies." Science. https://doi.org/10.1126/ science.aay940.

Corea, G. 1986. The Mother Machine: Reproductive Technologies from Artificial Insemination to Artificial Wombs. MCN: The American Journal of Maternal/Child Nursing 11 (5): 357-363.

Cyranoski, D. 2019. Russian 'CRISPR-baby' Scientist Has Started Editing Genes in Human Eggs 
with Goal of Altering Deaf Gene. Nature 2019 574:7779.

Dawkins, R. 2006. The Selfish Gene: 3oth Anniversary edition. Oxford: OUP. https:// books.google.ru/books?id=EJeHTt8hW7 $\mathrm{U}$.

DeVries, W. C., J. L. Anderson, L. D. Joyce, F. L. Anderson, E. H. Hammond, R. K. Jarvik, and W. J. Kolff. 1984. "Clinical Use of the Total Artificial Heart." New England Journal of Medicine, 310 (5): 273-278. https://doi.org/10.1056/ NEJM19840202310050.

Ear Foundation, The. 2017. "Cochlear Implant Information Sheet.". The Ear Foundation. (July 11). https://web.archive.org/ web/20170711192446/http://

www.earfoundation.org.uk/files/ download/1221. Accessed 1 October 202.

Farina, D., and O Aszmann. 2014. "Bionic Limbs: Clinical Reality and Academic Promises." Science Translational Medicine, 6 (257): 257+12. https://doi.org/10.1126/scitranslmed.301045.

Finch, J. L., G. H. Heath, A. R. David, and J. Kulkarni. 2012. "Biomechanical Assessment of Two Artificial Big Toe Restorations from Ancient Egypt and Their Significance to the History of Prosthetics." JPO: Journal of Prosthetics and Orthotics 24 (4): 181-191.

Fortune Business Insights. 2019. "Surgical Robots Market Size, Growth | Global Report, 2026." (June 1). https:// www.fortunebusinessinsights.com/industryreports/surgical-robots-market-100948. AccessedOctober 9, 2020.

Fukuyama, F. 2004. "Transhumanism." Foreign Policy (144): 42-43.

Goethe, J. W. n.d. Goetz von Berlichingen, 120.

Grinin, L., A. Grinin, and A. Korotayev. 2020. Technological Forecasting and Social Change: A Quantitative Analysis of Worldwide Longterm Technology Growth?: From 40,ooo BCE to the Early 22nd Century. Technological Forecasting and Social Change (July 2019), 119955. https://doi.org/10.1016/j.techfore.2020.11995.

Grinin, L., and A. L. Grinin. 2015. "Global Technological Perspectives in the Light of Cybernetic Revolution and Theory of Long Cycles." Journal of Globalization Studies, 6 (2).
--. 2016. The Cybernetic Revolution and the Forthcoming Epoch of Self-regulating Systems. Moscow: Uchitel Publishing House.

Grinin, L., and A. Korotayev. 2013. "Globalization and the World System Evolution." Evolution: Development within Big History, Evolutionary and World-system Paradigms. Yearbook, 3068.

Grinin, L. E., A. L. Grinin, and A. Korotayev. 2016. "Forthcoming Kondratieff Wave, Cybernetic Revolution, and Global Ageing. Technological Forecasting and Social Change. https:// doi.org/10.1016/j.techfore.2016.09.o1.

Haldane, J. B. S. 1924. Daedalus or Science and the Future. New York: E P Dutton.

Hansell, G. R. and W. Grassle. 2011. H+/-: Transhumanism and Its Critics. Bloomington, IN: Xlibris Corporation.

Hirose, M., and K. Ogawa. 2007. "Honda Humanoid Robots Development." Philosophical Transactions of the Royal Society A: Mathematical, Physical and Engineering Sciences, 365 (1850): 11-19. https://doi.org/10.1098/ rsta.2006.191.

Huxley, J. 2015. "Transhumanism." Ethics in Progress, 6 (1): 12-16.

Jones, S. E. 2013. Against Technology: From the Luddites to Neo-Luddism. New York: Routledge.

Joy, B. 200o. "Why the Future Doesn't Need Us." Wired (April 1). https://www.wired.com/200o/ 04/joy-2/. Accessed October 8, 2020.

Kurzweil, R. 2010. The Singularity is Near. London: Gerald Duckworth \& Co.

Lem, S. 1968. Summa Tekhnologii. Kraków: Wydawnictwo Literacki.

More, M. 2013. "The Philosophy of Transhumanism." The Transhumanist Reader, 8.

Murphy, S. V. and A. Atala. 2014. 3D Bioprinting of Tissues and Organs. Nature Biotechnology, 32 (8): 773-785. https://doi.org/10.1038/ nbt.295.

Ong, J. M., and L. da Cruz. 2012. "The Bionic Eye: A Review." Clinical and Experimental Ophthalmology, 40 (1): 6-17. https://doi.org/10.1111/ j.1442-9071.2011.0259.

Peercy, P. S. P. 2000. "The Drive to Miniaturization." Nature 406 (6799): 1023-6. https:// 
doi.org/10.1038/3502322.

Pelegrín-Borondo, J., M. Arias-Oliva, K. Murata, and M. Souto-Romero. 2020. "Does Ethical Judgment Determine the Decision to Become a Cyborg?: Influence of Ethical Judgment on the Cyborg Market." Journal of Business Ethics, 161 (1): 5-17. https://doi.org/10.1007/ S10551-018-3970-.

Rosen, C. 2003. "Why Not Artificial Wombs?" The New Atlantis (3): 67-76.

Schalk, G., D. J. McFarland, T. Hinterberger, N. Birbaumer, and J. R. Wolpaw. 2004. "BCI200o: A General-purpose Brain-computer Interface (BCI) System.” IEEE Transactions on Biomedical Engineering 51 (6): 1034-1043. https:// doi.org/10.1109/TBME.2004.82707.

Sellegren, K. R. 1982. "An Early History of Lower Limb Amputations and Prostheses." The Iowa Orthopaedic Journal 2, 13-27.

Spier, F. 2015. Big History and the Future of Humanity. New York: John Wiley \& Sons.

Stamatialis, D. F., B. J. Papenburg, M. Gironés, S. N. M. Bettahalli, S. Schmitmeier, and M. Wessling. 20o8. "Medical Applications of Membranes: Drug Delivery, Artificial Organs and Tissue Engineering." Journal of Membrane Science 308 (1-2): 1-34. https://doi.org/10.1016/ j.memsci.2007.09.05

Statista. 2015. "Life Expectancy at Birth Forecast United Kingdom 2013-206o Statistic." Statista. (May 20). https://www.statista.com/ statistics/478512/life-expectancy-birthforecast-united-kingdom-uk. Accessed October 9, 2020.

Technavio. 2016. "The Number of Cochlear Implants Shipped Worldwide is Expected to Hit 96,00o by 2020." Technavio. (February 1) https://blog.technavio.com/blog/numbercochlear-implants-shipped-worldwideexpected-hit-96000-2020. Accessed 1 October 2020.

---. 2020. "Robotic Simulator Market Will Showcase Neutral Impact during 2020-2024 | Growing Need for Robotic Simulation to Boost Market Growth." Technavio. (October 7). https://www.businesswire.com/news/ home/20201007005757/en/Robotic-SimulatorMarket-will-Showcase-Neutral-Impact-during
-2020-2024-Growing-Need-for-Robotic-

Simulation-to-Boost-Market-Growth-

Technavio. 2020. Accessed 1 October 2020.

Tepe, M., and P. Vanhuysse. 20o9. "Are Aging OECD Welfare States on the Path to Gerontocracy? Evidence from 18 Democracies, 19802002." Journal of Public Policy, 1-28.

Vollset, S. E., E. Goren, C.-W. Yuan, J. Cao, A. E. Smith, T. Hsiao, et al. 2020. "Fertility, Mortality, Migration, and Population Scen-arios for 195 Countries and Territories from 2017 to 2100: A Forecasting Analysis for the Global Burden of Disease Study." The Lancet. https:// doi.org/10.1016/So140-6736(20)30677-.

von Weizsäcker, E. U., and A. Wijkman. 2018. Come on!: Capitalism, Short-termism, Population and the Destruction of the Planet. Springer. Semantic Scholar. Allen Institute for AI.

Wang, X., Z. Mei, Y. Wang, and L. Tang. 2015. "Gold Nanorod Biochip Functionalization by Antibody Thiolation." Talanta 136, 1-8. https://doi.org/10.1016/j.talanta.2014.11.02.

Wilson, A. Bennett. 1964. "Limb Prosthetics Today." Physical Therapy, 44 (6): 435-469. https://doi.org/10.1093/ptj/44.6.435.

WHO. 2020. "Current Health Expenditure as a Percentage of Gross Domestic Product (GDP)." WHO. (October 6) World Health Organization. http://www.who.int/gho/ health_financing/health_expenditure/en. Accessed 6 October 2020.

World Bank. 2011. "New World Report Shows More than 1 Billion People with Disabilities Face Substantial Barriers in Their Daily Lives." WHO (June).

Wu, Z., Y. Zhou, Z. Shi, C. Zhang, G. Li, X. Zheng, et al. 2016. "Cyborg Intelligence: Recent Progress and Future Directions." IEEE Intelligent Systems 31 (6), 44-50. https://doi.org/10.1109/ MIS.2016.10

$\mathrm{Xu}$, N., O. Lenczewska, S. Wieten, C. Federico, and J. Dabiri. 2020. "Ethics of Biohybrid Robotic Jellyfish Modification and Invertebrate Research." https://doi.org/10.20944/ preprints202010.0008.v.

Yeoman, I., and M. Mars. 2012. "Robots, Men and Sex Tourism.” Futures 44 (4), 365-371. https:// doi.org/10.1016/j.futures.2011.11.0o. 


\section{Endnotes}

${ }^{1}$ It is important to mention that Cybernetic revolution itself is a continuation of a major trend. On the macro scale, technological growth has been increasing, at least over the past 40,0oo years, albeit with fluctuations (Grinin, Grinin, Korotayev 2020).

${ }^{2}$ This is multi-millionaire David Rockefeller, who underwent his last operation, a heart transplant, at the age of 99 .

${ }^{3}$ We are constantly facing such shocks; therefore, the issue raised by Alvin Toffler in his wellknown Future Shock nearly half a century ago still remains relevant (Toffler 1970). 